briefly the history of radiochemistry, he concludes that a place is needed where the results now published in a variety of journals can be brought together. One could give wholehearted support to this view if every paper published fitted neatly into only one of the subdivisions of science and if the boundaries of the subdivisions were unambiguous. However, it is of the nature of science that these two conditions are rarely, if ever, satisfied.

This is well exemplified by the contents of the first number of this journal, which comprises ten papers and two short notes. One paper is straight radiation chemistry, two are concerned with hot atom chemistry, one with complexes of neptunium IV and one is a somewhat technological approach to fractional solvent extraction separation procedures. One cannot help feeling that most of these papers might easily have found a much wider range of readers by publication in the established chemical journals. To have an additional journal for papers of this kind recalls the words of the sonnet "So all ... is dressing old words new, spending again what is already spent". In short, interested workers must pay again to read those papers which they should reasonably be able to expect to find in the journals to which they already subscribe. This is not a situation in which one can welcome another new journal, unless it promises to be of unusually high quality and to meet a really important need which, in this case, seems unlikely.

\section{The National Museums of Ceylon}

The National Museums of Ceylon clearly recognize research as one of their functions, and the current issue of Spolia Zeylanica, bulletin of the National Museums of Ceylon (29, Part II; 1962), gives renewed proof of the value of their work. The part includes papers on geology, zoology and anthropology, many written by the director, Dr. P. E. P. Derniyagala. The papers are all well produced and illustrated.

\section{Glossary of Atomic Terms}

THE fourth edition of the booklet Glossary of Atomic Terms has been published by the U.K. Atomic Energy Authority. It provides a convenient collection of easily understood definitions of more than 400 terms and abbreviations used in atomic energy. This glossary is intended to be of help to those who are studying atomic energy for the first time. It may therefore be regarded more as a layman's manual of instruction than a source book of highly scientific definitions. For those already familiar with underlying principles, more technically precise definitions have been published by the British Standards Institution in their glossary $B S$ 3455: 1962. The glossary is available from H.M.S.O. at $3 s$. $6 d$. net.

\section{Italian Rock Carvings}

Is the foothills of the north Italian mountains there are several areas where prehistoric figures of animals, signs and weapons occur, carved on rock surfaces. The most famous series has long been known, thanks to the research work of the late C. Bicknell. They occur in the Ligurian Alps around Monte Bego, inland from Mentone. Another group, to be found in the Val Camonica where the valley debouches on to the north Italian plain, was described some years ago by Prof. Marro. While differing in several respects from the Monte Bego series, the Val Camonica art is undoubtedly, culturally speaking, connected with it, and both can be dated to the
Early Metal Age. Superpositions make it possible to determine several slightly differing 'layers' at the Val Camonica. More recently, Dr. E. Anati has studied this region, and in the August issue of Man he has published a note on some figures of halberds, occurring at a site called locally Roccia dei Corni Freschi which lies near the River Oglio, just north of where it enters the Iseo Lake. Figures of halberds also oceur at Monte Bego, but the types are not identical. An important book on his campaigns in the Val Camonica has recently been published by Dr. Anati in the United States, but for some copyright reason the work cannot be obtained in Great Britain.

\section{Anæsthesia and Analgesia}

Advances in anrsthesia are among the most dramatic in the whole field of medicine. Inevitably, these advances have meant an increasing degree of specialization, with the result that, outside the sphere of domiciliary obstetrics, relatively few general practitioners have now much experience in anæsthetics. Anæsthesia, however, as Prof. Beecher points out in an article in a symposium on "Anæsthesia and Analgesia" in the August issue of The Practitioner (189, No. $1130 ; 1962$ ), is merely a branch of one of the most fundamental problems in medicine-the relief of pain. It is incumbent on all clinicians to keep in touch with what is being achieved in this field. To help them do so is the purpose of this symposium. In spite of increasing specialization-or perhaps because of it-society is gradually re-learning the old lesson that the essence of the practice of medicine is holism. The patient, not his disease, is the primary concern of the doctor. Nowhere is this truer than in the alleviation of pain-whether by anæsthetic, analgesic or human sympathy.

\section{University News:}

Belfast

THE following appointments to lectureships have been announced: J. Graham (civil engineering); Dr. J. H. Jones (dental pathology); A. Brown (mechanical engineering); Dr. A. M. Rosie (light electrical engineering).

Cambridge

C. Strachey, of King's College, has been elected to a senior research fellowship (Title $B$ ) at Churchill College.

Columbia

Dr. Tsung-Dao Lee is rejoining the Columbia University Department of Physics as a full-time member of the teaching staff. For the past two years, Dr. Lee has been adjunct professor of physics at Columbia, while serving as a member of the Institute for Advanced Study at Princeton. His new title at the University for the 1962-63 academic year will be visiting professor of physics. It was while he was a member of the Columbia Department of Physics that Dr. Lee was awarded the 1957 Nobel Prize in Physics jointly with Dr. Chen Ning Yang, of the Institute for Advanced Study, for their work in the disproof of the 'principle of conservation of parity'.

\section{London}

THe following titles have been conferred: Professor, on Dr. R. L. F. Boyd (physics), in respect of his post at University College; on Dr. Florence N. David (probability and statistics), in respect of her post at University College; on Dr. Leonard Saunders (phar- 